\title{
Research on College Students' Entrepreneurial Model
}

\author{
Xiaoqin $\mathrm{Wu}$ \\ Shandong Technology and Business University \\ Yantai, Shandong, 264005 \\ 11747612@qq.com
}

\begin{abstract}
Comparative study is adopted in this thesis to analyze three entrepreneurial models of college students under the current situation in China to find out the entrepreneurship models that are suitable for Chinese college students under the current social environment. By combining with the actual situation in China, analyzing the advantages and disadvantages of various models and evaluating them, the optimal mode for China's national conditions can be found. Therefore, this thesis can provide the theoretical guidance as well as the theoretical support for college students' entrepreneurship in China.
\end{abstract}

Keywords—College Students; entrepreneurship; model

\section{The NeCESSiTY OF COLLEGE STUdents' ENTREPRENEURSHIP}

Though college students' entrepreneurship is brand-new, it is of great significance to the social development and economic growth. Firstly, it can help college students cultivate innovative ability and spirit as well as practical ability consciously. Entrepreneurship does not just influence the students who start their business. The contemporary college students is ambitious of success and worship heroes, so they can be inspired by the successful examples and most of them can be led to reflect upon their own intellectual structure as well as personal qualities and then improve themselves in action. It is not only consistent with the requirements of student' quality-oriented education and the growth of young students, but also is an impact on the traditional higher education. Second, it makes great contribution to the social development and economic growth. Optimal utilization has become one of the main contents in the economic development while the space for improving the efficiency of modern economic system has gradually narrowed. Therefore, innovation has become the key factor of economic development. Entrepreneurship not only improves the per-capita output and income level of individuals, but also promotes the formation of new social structure and economic one. As college students live in the campus, a place where Chinese research activities are concentrated, entrepreneurship plays a special role in improving Chinese laggard conversion rate of knowledge. Meanwhile, no matter succeeding or not, it will cultivate a group of talents with high cultural level and rich practical experience for the society. The strategic significance of social development is far greater than the simple economic one[1].

Fund Project: Phase Outcomes of "Research on Ideological and Political Education of Undergraduates with New Media Innovation" (Project No. 2015XSZX016) Project of Young Scientists Fund of Shandong Business School (Special Project for Education and Management of Students).

\section{ANALYSIS ON COLLEGE STUDENTS’ ENTREPRENEURIAL MODEL}

\section{A. The classification of the model}

The entrepreneurial models of college students can be divided into the following three categories according to the time on which college students participate in entrepreneurship: part-time entrepreneurship, suspension-of-schooling entrepreneurship and post-college entrepreneurship. These three modes are the selection results of college students' entrepreneurship practice. In this chapter, their characteristics and applicability will be discussed respectively, and these three models will be compared to provide some guidance for college students in the choice of entrepreneurial models[2].

\section{1) Part-time entrepreneurship}

Part-time entrepreneurship refers to the entrepreneurial model that students are engaged in the entrepreneurial activities in their spare time without giving up or interrupting their university learning. From the perspective of college students entrepreneurs, the choice of this model is mainly in the following situations. Firstly, the purpose of entrepreneurship serves for the learning in college. That is to say, entrepreneurial activities carried out by college students help them better complete the university learning, which can be classified into two categories. One is to raise the school expenses; the other is to train their practical ability. Secondly, the risk of starting a business is so high for college students entrepreneurs that they choose part-time entrepreneurship in order to own more options after the failure of self-entrepreneurship. Thirdly, due to the pressure as well as the dependence on the society and family, which has been clarified in the front part of the thesis, college students have to ask the permission of their families and social members when they choose the entrepreneurial model.

The characteristics of part-time entrepreneurial model: Firstly, the diversity of entrepreneurial management models. Entrepreneurs will not only face the business risks and challenges but also have to complete heavy university courses, so they can just use their spare time to engage in business. Besides, because of the inflexibility of the education system, the operation mode of the enterprise has to adjust according to the actual situation of entrepreneurs. Secondly, the diversity of entrepreneurial organizational forms. On the one hand, it is because the diversity of the source of venture capital. On the 
other hand, the university campus is more independent than the society; some entrepreneurial activities are limited or have informal legal forms. Thirdly, the average content of science and technology in enterprises is relatively low, which is, on the one hand, determined by the overall situation of China's entrepreneurship, and on the one hand, caused by the defection of the professional technical knowledge of college students, especially those of low grade.

According to the influence factors of college students' entrepreneurship, the main reasons for choosing this model are as follows: one is that college students lack the assurance of victory for their own business; the other is that family and society require them not to influence their school work when they start their own business.

\section{2) Suspension-of-schooling entrepreneurship}

Suspension-of-schooling entrepreneurship refers to a model that students apply for suspension of schooling to start business activities, which is greatly influenced by the educational system. Such an application for the suspension of schooling is hard to be approved because scholastic year system or incomplete credit system is implemented in most China's colleges and universities. It can also be called buffered model, that is, entrepreneurial college students can make more targeted choices of entrepreneurial model through their own practice and the development of entrepreneurial enterprises in the period of the temporary absence from school[3].

The characteristics of suspension-of-schooling entrepreneurship are as follows: first of all, entrepreneurial college students have enough time and effort to conduct business and suspension of schooling can provide them with more rich practice and experience, which is beneficial to their success of entrepreneurship. In the second place, as entrepreneurs have relatively strong bear ability to the failure, under the same conditions, this model provides a launch mechanism for entrepreneurs. Last one is variability. As a result of the time limit of the suspension of schooling, entrepreneurial college students should choose between the other two models and then turn into one of them according to the actual situation in their suspension-of-schooling entrepreneurship.

From the influence factors of entrepreneurship, it, first of all, requires that college students should be confident of their entrepreneurial plans and self-capability. Secondly, it needs the acceptance and support of family, school and society.

\section{3) Post-college entrepreneurship}

This model refers to the situation that college students start business after their graduation. The motivation of those college students who choose this kind of model stems from the need for self-actualization or employment. It has small impact for higher education. Besides, the quality all aspects like entrepreneurial ability and personal knowledge level will be greatly improved in the process of higher education. Meanwhile, the improvement of self-quality lead to a larger choice scale in the course of entrepreneurship, which plays a great role in the success of entrepreneurs. From the perspective of the significance of college students' entrepreneurship, the effect of this model is extraordinary for developing the social economy and eliminating the employment pressure of students. Therefore, it should be strongly advocated and guided in China.

The characteristics of post-college entrepreneurship are as follows: firstly, it has no impact for the higher education. Secondly, the organization form and operation mode of the entrepreneurial enterprises are relatively stable[4]. As college students of the post-college entrepreneurship will directly face the opportunities and challenges of the market economy, the regular form of enterprises is indispensable. Therefore, the management skills of entrepreneurs must be improved in this model. Thirdly, the average of technical content of entrepreneurial enterprises is high. After acquiring the college education, the professional skills and social practice ability of the students are greatly improved, which can make the larger possibility of private technical entrepreneurship and is good for better grasp of the development of the related technical field. It also increases the possibility of using advanced technology in start-ups.

According to the time of participating in the entrepreneurship, there is another model called drop-out entrepreneurship. However, the higher education in current China has been gradually transformed into basic education and ability education. Giving up this phase of the study has more harm than good for the growth of college students.

\section{B. Decision conditions for business model}

First, college students are mostly between the age of 18 and 25 , the golden age for learning. Second, university education has also gradually transformed from elite education to mass education due to the reform of higher education. Therefore, the degree of university education has a great impact on the growth and development of undergraduates. In this connection, which business model to choose becomes the first problem when one decides to start a business, [5]. In this section, we discuss the preconditions that affect the choice of entrepreneurial model for college students. (1) personal goals; (2) entrepreneurial risk; (3) initial resources; (4) timeliness of entrepreneurial opportunities.

\section{Model assessment}

University students' innovative undertaking is a systematic project, which is of great significance to both college students and social and economic development. Therefore, when we assess the model, we should not only proceed from the microperspective of undergraduates themselves but also from the macro-perspective of social development. Therefore, the merits of a model of entrepreneurship are mainly the impact of entrepreneurship on the entrepreneur himself and the impact on social and economic development and the feasibility of such a model. Consequently, we make out the following three principles to assess these three models. (1) the benefit to individual development of entrepreneur (2) the benefit to social economic development (3) Feasibility. In the following passage, we will discuss in detail from the above three aspects: (1) benefit to the development of entrepreneurs; (2) benefit to social and economic development; (3) feasibility. 


\section{RECOMMENDATIONS}

\section{A. Improve education system in our country}

The innovative spirit can't be fully cultivated just in the university, rather, we should keep instilling in our children and students entrepreneurial concepts in school and family education, to cultivate their interest of starting businesses and practical skills. (1)Transform the education thinking, come out from the mode of examination-oriented education, and carry out the quality education to lay a good foundation for the entrepreneurship activities of college students (2)Learn from America to introduce the basic course of economics into primary and secondary education and train students business awareness and practical ability. (3) Set entrepreneurial courses in universities; improve students' basic knowledge of entrepreneurship, in order to avoid blindness in entrepreneurial activities. (4) Carry out entrepreneurship education throughout the country with labor security department and personnel department to get ready for the activities with abundant knowledge and to create a good environment for students' undertaking.

\section{B. Improve entrepreneurial laws and regulations}

In China, a country that has been influenced by thousands of years of Confucian culture, the role of the government can't be ignored in the promotion of a new thing. In this regard, South Korea has set a good example for us. We should seize the opportunity that our country is proceeding with the building of a law society to enrich the laws and regulations on entrepreneurship, especially on students entrepreneurship. (1) Launch laws and regulations aimed at college students 'entrepreneurship and introduce preferential measures for college students' entrepreneurship to guide and encourage college students to start their own businesses. (2) Due to the large number of college students in our country, it is unrealistic to solely rely on the government or the school investment at the beginning of business launching. Therefore, we should make use of the relevant policies to attract the idle social capital and look for other assistance. (3) Speed up the reform of the education system, to reform student status management and other rules and regulations in colleges and universities, in order to remove the barriers in student entrepreneurship and help students start their own businesses.

\section{Accelerate the construction of market economy}

Improve our country's venture capital mechanism. The difficulties in fund raising are outstanding in China's college students entrepreneurship, for which the main reasons are: (1) the national credit rating system has not yet been established (2) the venture capital mechanism itself is not perfect (3) entrepreneurial measures have not been introduced. The weaknesses has turned out to be great obstacles in getting financial enterprises loans, venture capital, capital market financing ---the capital sources of students startups, which are also the main sources of fund raising, especially in some hightech startups ,for college students in the United States that has the best momentum in students business development. Therefore, accelerating market economy construction in our country and perfecting the construction of financial and capital markets are the preconditions in our country to vigorously promote the entrepreneurship among students and the public.

\section{Give full play to the government's macro-control function and establish a social support system}

In view of the current situation of undergraduate entrepreneurship in our country, after the introduction of corresponding policies and regulations, the government should play its leading role in organizing universities, research institutes and enterprises to form a non-profit organization of "Students' Entrepreneurship Guidance Association", of which the main functions are the following: (1) project review: to help students with feasibility analysis and guidance start-up business. (2) management consulting, technical support: This is a great help to make up for their lack of management experience and technology .

\section{E. Intensify positive guidance and education}

University students' innovative undertaking is crucial for the growth of students from a micro perspective, and it plays a decisive role in the economic development of our country from a macro perspective. Therefore, when giving guidance and education , the family, school and the society should not only consider how to promote the growth and development of undergraduates, but also give full consideration to the great strategic significance of the undertaking of undergraduates, in order to make the undergraduates venture towards postuniversity start-up which contributes most to social development .

\section{CONCLUSIONS}

According to the time when college students start their own businesses, the models of college students' entrepreneurship can be classified into part-time start-up, post-secondary start-up and post-university start-up. And an evaluation model for college students' entrepreneurship has been formulated, with which analysis has been made in the actual cases of the three models. The conclusion is that, for our country's current situation, the best model is post-university start-up which also needs to be vigorously promoted and guided by us.

\section{REFERENCES}

[1] Chen Dezhi "Entrepreneurship Management" Tsinghua University Press(In Chinese)

[2] Guo Biyu "reflection on the problems of college students entrepreneurship" Huai Yin Institute of Technology 2/2003(In Chinese)

[3] Cai Xinping "on the entrepreneurial ability of college students" Journal of Hunan Agricultural University 3/1/2000(In Chinese)

[4] Xie Zhiyuan, Ying Yunjin "On entrepreneurship education of college students" Jiangsu Higher Education 3/2003(In Chinese)

[5] Tao Huanxiang "college students should pay attention to several issues" Economic front 12/2000(In Chinese) 